\title{
PENGARUH PEMBERIAN TUGAS MANDIRI TERSTRUKTUR TERHADAP HASIL BELAJAR FISIKA MADRASAH TSANAWIYAH NURUL HUDA
}

\author{
Siti Anisatur Rofiqah1, Erwin², dan Wahid Gunarto ${ }^{3}$ \\ 1,2,3 Prodi Pendidikan Fisika STKIP Nurul Huda \\ 1,2,3 Jl. Kotabaru Sukaraja Buay Madang OKU Timur Sumatera Selatan \\ anisamuzakki89@gmail.com
}

\begin{abstract}
Abstrak
Penelitian ini bertujuan untuk mengetahui hasil belajar fisika siswa yang telah diberi tugas mandiri struktur. Metode dalam penelitian ini adalah eksperimen dengan desain quasi eksperiment. Populasi dalam penelitian ini adalah seluruh siswa kelas VIII MTs Nurul Huda tahun pembelajaran 2011/2012. Pengambilan sampel dilakukan secara acak yaitu kelas VIII-1 sebagai kelas kontrol dan kelas VIII-4 sebagai kelas eksperimen. Data tes hasil belajar diperoleh dengan pemberian tugas mandiri terstruktur. Perhitungan statistik uji Z yang digunakan untuk uji hipotesis pada penelitian ini menggunakan taraf signifikan ( $\alpha=5 \%$ ) Hasil penelitian menunjukkan bahwa terdapat pebedaan hasil belajar siswa yang diberi tugas mandiri terstruktur dengan yang tidak diberi tugas mandiri terstruktur dengan hasil perhitungan diperoleh nilai $Z_{\text {hit }}=4,01$ tidak terletak antara $-1,96$ dan 1,96 sehingga $\mathrm{H}_{\mathrm{o}}$ ditolak dan $\mathrm{H}_{\mathrm{a}}$ diterima. Skor hasil belajar fisika dengan menggunakan metode pemberian tugas mandiri terstruktur lebih tinggi dibandingkan dengan yang tidak diberikan tugas mandiri terstruktur yaitu rata-rata nilai kelas eksperimen 73,69, varians 122,59 dan standar deviasi 11,07. Sedangkan rata-rata nilai kelas kontrol 63,90, varians 74,34 dan standar deviasi 8,62.
\end{abstract}

Kata kunci: hasil belajar, tugas mandiri terstruktur.

\section{PENDAHULUAN}

Berhasil atau tidaknya pencapaian pembelajaran banyak terjadi kepada bagaimana proses belajar yang dialami oleh siswa sebagai peserta didik. Agar peserta didik aktif dalam proses pembelajaran fisika, dan materi pelajaran fisika yang diperoleh pada pertemuan sebelumnya dapat diingat dan tidak terlupakan begitu saja. Untuk itu pendidik harus memilih metode yang tepat dalam proses pembelajaran di kelas merupakan cara untuk mencapai tujuan pembelajaran. Salah satu metode yang bisa diberikan adalah dengan memberikan soal-soal lewat tugas. Pemberian tugas ini bisa terlihat pengaruhnya ketika diberikan beberapa kali dalam tiap pertemuan, bisa diakhir ataupun pada waktu jam pelajaran setelah materi diberikan dengan batasan waktu yang telah ditentukan. Setelah beberapa kali tugas ini diberikan, hasil belajar peserta didik yang diberi tugas dan yang tidak diberi tugas baru bisa dilihat perbedaannya. Tujuan dari penelitian ini adalah :

1. Untuk mengetahui bagaimana hasil belajar fisika siswa yang diberi Tugas Mandiri Terstruktur.

2. Untuk mengetahui bagaimana hasil belajar fisika siswa yang tanpa diberi Tugas Mandiri Terstruktur.

3. Untuk mengetahui perbedaan hasil belajar fisika siswa yang signifikan antara yang diberi Tugas Mandiri Terstruktur.

Secara teoritis manfaat penelitian ini sebagai berikut:

1. Memberikan konstribusi tentang adanya pemberian Tugas Mandiri Terstruktur pada pembelajaran fisika pada pokok bahasan bunyi di kelas VIII MTs Nurul Huda Sukaraja.

2. Membantu siswa dalam meningkatkan hasil belajar fisika di kelas VIII MTs Nurul Huda pada pokok bahasan bunyi yang tidak diberi 
Tugas Mandiri Terstruktur dan diberi Tugas Mandiri terstruktur.

3. Manfaat bagi peneliti yaitu membantu memberikan pengalaman dalam menggunakan metode pemberian Tugas Mandiri Terstruktur pada pembelajaran sehingga hasil yang dicapai lebih efektif, efisien dan dapat dikembangkan dalam proses pembelajaran khususnya fisika.

Hipotesis dalam penelitian ini adalah:

1. $\mathrm{H}_{0}=$ Tidak terdapat perbedaan hasil belajar fisika siswa yang signifikan antara yang diberi Tugas Mandiri Terstruktur dan yang tanpa diberi Tugas mandiri terstruktur.

2. $H_{a}=$ Terdapat perbedaan hasil belajar fisika siswa yang signifikan antara yang diberi Tugas Mandiri Terstruktur dan yang tanpa diberi Tugas mandiri terstruktur.

\section{METODE/EKSPERIMEN}

Desain penelitian yang akan digunakan dalam penelitian ini adalah desain penelitian quasi eksperiment. Quasi eksperiment merupakan eksperimen tidak sebenarnya, oleh karena itu sering disebut juga dengan istilah "eksperimen pura-pura". Karena eksperimen ini belum memenuhi persyaratan seperti cara eksperimen yang dapat dikatakan ilmiah mengikuti peraturan-peraturan tertentu. Desain penelitian ini kelas yang lain sebagai kelas kontrol (tidak dikenai perlakuan), desainnya sebagai berikut:

Tabel 1 Desain penelitiannya menggunakan:

\begin{tabular}{llll}
\hline Kelompok & Pretest & Perlakuan & Postest \\
\hline Kontrol & $\begin{array}{l}\text { Nilai rata- } \\
\text { rata pretest } \\
\text { kelas control }\end{array}$ & & Nilai \\
& $\left(\mathrm{O}_{1}\right)$ & $\begin{array}{l}\text { rata-rata } \\
\text { post test } \\
\left(\mathrm{Y}_{1}\right)\end{array}$ \\
\hline Eksperimen & $\begin{array}{l}\text { Nilai rata- } \\
\text { rata pretest }\end{array}$ & Perlakuan & Nilai \\
& kelas & diterima & rata-rata \\
& Eksperimen test \\
& $\left(\mathrm{O}_{2}\right)$ & $(\mathrm{X})$ & $\left(\mathrm{Y}_{2}\right)$ \\
& & &
\end{tabular}

Pada penelitian ini terdapat dua variabel yaitu variabel bebas dan variabel terikat. Variabel bebas adalah pemberian tugas mandiri terstruktur, sedangkan variabel terikat adalah hasil belajar di kelas VIII MTs Nurul Huda tahun pembelajaran 2011/2012
Sampel dalam penelitian ini terdiri dari dua kelas yaitu satu kelas sebagai kelas eksperimen dan satu kelas sebagai kelas kontrol siswa kelas VIII MTs Nurul Huda tahun pembelajaran 2011/2012. Pengambilan sampel dalam penelitian ini dilakukan dengan teknik Simple Random Sampling. Instrumen yang diperlukan untuk keperluan pengumpul data dalam penelitian ini adalah lembar tes. Dalam pengumpulan data, siswa kelas eksperimen dan kelas kontrol diberikan soal berbentuk essay yang terdiri dari 5 butir tes (item) sesuai dengan indikator materi mengenai bunyi. Beberapa Uji Instrumen dalam Penelitian ini antara lain:

\section{Validitas}

Sebuah intrumen dikatakan valid apabila mampu mengukur apa yang diinginkan dan dapat mengungkap data dari variabel yang diteliti secara tepat.

Rumus korelasi yang digunakan adalah yang dikemukakan oleh pearson, yang dikenal dengan rumus korelasi product moment dengan rumus angka kasar sebagai berikut:

$$
r_{x y}=\frac{N \sum x y-\left(\sum x\right)\left(\sum y\right)}{\sqrt{N \sum x^{2}-\left(\sum x\right)^{2}\left(N \sum y^{2}\right)-\left(\sum x\right)^{2}}}
$$

Dengan pengertian:

$r_{x y}=$ Koefisien korelasi antara variabel $\mathrm{X}$ dan $\mathrm{Y}$.

$\sum x y=$ perkalian antaras $x$ dan $y$

$X^{2}=$ Kuadratdari $x$

$Y^{2}=$ Kuadrat dari $y$

Kriteria suatu instrumen dikatakan valid apabila koefisien korelasi product moment ( $\mathrm{r}_{\text {hit }}$ ) $>\left(r_{\text {tabel }}\right)$. Adapun $r_{\text {tabel }}$ dapat ditentukan dengan $r(\alpha: n-2)$, dengan $n$ adalah jumlah siswa. Taraf signifikansi sebesar $5 \%(\alpha=5 \%)$.

\section{Reliabilitas}

Reliabilitas menunjuk pada suatu pengertian bahwa suatu instrumen cukup dapat dipercaya untuk digunakan sebagai alat pengumpul data karena instrumen tersebut sudah baik. Untuk menguji soal tersebut menggunakan rumus Alfa Cronbach :

$$
r_{i}=\frac{k}{(k-1)}\left\{\frac{\sum S i^{2}}{S t^{2}}\right\}
$$

Keterangan:

$K=$ mean kuadrat antar subjek 
$\sum \mathrm{Si}^{2}=$ mean kuadrat kesalahan

$S_{t}{ }^{2} \quad=$ varians total

Soal dikatakan reliabel jika memenuhi syarat $r_{i}$ $>0,6$

\section{Tingkat Kesukaran}

Bilangan yang menunjukkan sukar dan mudahnya suatu soal disebut indeks kesukaran. Adapun rumus yang dipakai sebagai berikut:

$$
(P)=\frac{\mathrm{B}}{\mathrm{js}}
$$

Keterangan:

$\mathrm{P}=$ indeks kesukaran

$B=$ jumlah seluruh peserta tes

Js = banyaknya siswa yang menjawab dengan benar

Klasifikasi indeks kesukaran sebagai berikut:

- Soal dengan $p=0,00-0,30$ adalah soal sukar

- Soal dengan $p=0,30-0,70$ adalah soal sedang

- Soal dengan $p=0,70-1,00$ adalah soal mudah

Soal-soal yang akan digunakan dalam penelitian ini mencakup soal yang sulit $(25 \%)$, sedang (25\%), mudah (50\%).

\section{Daya Pembeda}

Daya pembeda soal diperlukan untuk mengetahui seberapa akurat butir pertanyaan itu membedakan subjek yang lebih mampu dari subjek yang kurang mampu Rumusnya:

$$
\mathrm{D}=\frac{B A}{J A}-\frac{B B}{J B}=\mathrm{P}_{\mathrm{A}}-\mathrm{P}_{\mathrm{B}}
$$

Keterangan:

$\mathrm{D}$ = Nilai daya pembeda

$\mathrm{JA}=$ Banyaknya peserta tes kelompok atas

$\mathrm{JB}=$ Banyaknya peserta tes kelompok bawah

$\mathrm{BA}=$ Banyaknya peserta tes kelompok atas yang menjawab soal benar

$\mathrm{BB}=$ Banyaknya peserta tes kelompok bawah yang menjawab soal benar

$\mathrm{P}_{\mathrm{A}}=$ Proporsi Banyaknya peserta tes kelompok atas yang menjawab soal benar

$\mathrm{P}_{\mathrm{B}} \quad=$ Proporsi peserta tes kelompok bawah yang menjawab soal benar

Klasifikasi daya pembeda adalah sebagai berikut:

- Jika D antara 0,00 sampai 0,20 maka soal tersebut jelek.
- Jika D antara 0,20 sampai 0,40 maka soal tersebut cukup.

- Jika D antara 0,40 sampai 0,70 maka soal tersebut baik.

- Jika D antara 0,70 sampai 1,00 maka soal tersebut sangat baik.

- Jika D negatif maka soal tersebut semuanya tidak baik.

Nilai daya pembeda yang akan digunakan adalah soal dengan $D>0,2$ dengan kriteria cukup, baik dan sangat baik.

\section{Uji Hipotesis}

\section{Uji Normalitas}

Uji Normalitas sebaran digunakan untuk memeriksa apakah data prestasi belajar siswa berdistribusi normal atau tidak. Uji normalitas dicari dengan menggunakan rumus Karl Person:

$$
K M=\frac{\bar{x}-m o}{s d}
$$

Dikatakan berdistribusi normal apabila harga Km terletak antara -1 dan +1 .

\section{Uji Homogenitas}

Uji homogenitas varians bertujuan untuk mengetahui sampel yang diamati dari populasi memiliki perbedaan varians atau sama. Data yang diuji ialah tes kemampuan awal siswa. Tes statistik untuk uji signifikan ini adalah uji F yaitu dengan membandingkan varians terbesar dengan varians terkecil dengan rumus sebagai berikut:

$$
\mathrm{F}_{\text {hit }}=\frac{S h^{2}}{S k^{2}}
$$

Kemudian F $F_{\text {itung }}$ dikonsultasikan dengan $F_{\text {tabel }}$ dengan derajat pembebasan pembilang $=\left(n_{b}-\right.$ 1) dan dengan derajat kebebasan bersyarat = $\left(n_{k}-1\right)$. kriteria pengujiannya adalah jika $f_{\text {hit }}<f_{\text {tab }}$ maka data yang diperoleh berdistribusi homogen. Dengan taraf signifikansi $5 \%$.

Setelah uji prasyarat menunjukkan sampel normal dan homogen maka selanjutnya di uji dengan uji $Z$ yang digunakan untuk uji hipotesis nihil tentang perbedaan Mean dari dua sampel/variabel. Masing-masing variabel berskala interval. Jadi untuk uji $Z$ menggunakan rumus:

$$
Z=\frac{\bar{X}_{1}-\bar{X}_{2}}{\sqrt{\frac{s_{1}{ }^{2}}{n_{1}}+\frac{s_{2}{ }^{2}}{n_{2}}}}
$$


Dengan kriteria uji terima $\mathrm{H}_{0}$ jika $-\mathrm{Z}_{1 / 2(1-\alpha)}<Z_{\text {hit }}<$ $Z_{1 / 2(1-\alpha)}$ dimana $Z_{1 / 2(1-\alpha)}$ didapat dari daftar normal baku dengan peluang $1 / 2(1-\alpha)$. Dengan taraf signifikansi $5 \%$.

\section{HASIL DAN PEMBAHASAN}

Penelitian dilaksanakan di kelas VIII MTs Nurul Huda Sukaraja pada bulan Juni 2012. Data yang diambil adalah tes hasil belajar siswa pada pembelajaran fisika pada pokok bahasan bunyi. Sebelum instrumen penelitian digunakan sebagai alat pengumpul data maka diuji terlebih dahulu kelayakannya. Instrumen penelitian terlebih dahulu diujikan pada siswa kelas VIII SMP PGRI Sumber Agung. Setelah diadakan pengujian instrumen tersebut diperoleh data yaitu 3 butir soal dinyatakan valid adalah butir soal nomer 2,3,4, dan 2 soal yang tidak valid adalah nomer 1 dan 5 . Soal yang tidak valid diperbaiki kemudian hasil pengujian ulang diperoleh bahwa butir soal telah valid.

Selanjutnya dilakukan pengujian reliabilitas dan diperoleh hasil 0,8>0,6. Instrument juga telah memiliki daya pembeda soal antara 0,20 sampai dengan 0,70 , artinya soal dalam instrument tersebut tergolong baik untuk membedakan tingkat kemampuan siswa. Sedangkan dari segi tingkat kesukaran soal diperoleh 1 butir soal sulit, 2 butir soal sedang dan 2 butir soal mudah. Soal tes hasil belajar fisika siswa berbentuk essay dengan jumlah 5 butir soal, untuk setiap jawaban benar memperoleh skor sesuai dengan skor yang telah ditentukan. Dengan kriteria uji terima $\mathrm{H}_{0}$ jika $-Z_{1 / 2(1-\alpha)}<Z_{\text {hit }}<Z_{1 / 2(1-\alpha)}$ dimana $Z_{1 / 2(1-\alpha)}$ didapat dari daftar normal baku dengan peluang $1 / 2(1-\alpha)$. Dengan taraf signifikansi 5\%. (Sudjana, 2005: 239).Ztabel $=Z 1 / 2(1-\alpha)=Z_{1 / 2(1-0,5)}$ $=Z 1 / 2(0,95)=Z_{0,475}$ Nilai $Z$ dari daftar normal baku dengan taraf signifikan $5 \%$ yang memberikan $Z=0,475$ adalah 1,96. Jadi kritreria pengujian yang dipakai adalah terima Ho jika $Z$ hit terletak antara $-1,96$ dan 1,96. Hasil perhitungan diperoleh nilai $Z_{\text {hit }}=4,01$ tidak terletah antara $-1,96$ dan 1,96 sehingga $H_{\circ}$ ditolak dan $\mathrm{H}_{\mathrm{a}}$ diterima yaitu Terdapat perbedaan hasil belajar fisika siswa yang signifikan antara yang diberi Tugas Mandiri
Terstruktur dan yang tanpa diberi Tugas mandiri terstruktur.

\section{PENUTUP}

Berdasarkan hasil analisis data dan pembahasan maka dapat disimpulkan bahwa tugas mandiri terstruktur yang ditugaskan kepada siswa dapat meningkatkan hasil belajar fisika dibandingkan dengan tidak menggunakan tugas mandiri struktur. Hal ini dapat dilihat dari skor rata-rata kelas eksperimen lebih tinggi dibandingkan dengan kelas kontrol. Melalui tugas mandiri terstruktur siswa dapat belajar lebih mandiri dalam memahami dan memecahkan masalah.

\section{DAFTAR PUSTAKA}

Arikunto, S. (2006). Prosedur Penelitian suatu pendekatan Praktik. Jakarta: Rineka Cipta.

Hasibuan, J.J\&Moedjiono. (2009). Proses Belajar Mengajar. Bandung: ROSDA.

Roestiani NK. (2008). Strategi Belajar mengajar. Jakarta:Rineka Cipta. Pp 132.

Sudjana, N., Ibrahim. (2009). Penelitian dan penilaian pendidikan. Bandung: Sinar Baru Algesindo. 